\title{
Management of Rectal Foreign Bodies: A Case Series Analysis
}

\section{Rektal Yabancı Cisimlerin Yönetimi: Olgu Serisi Analizi}

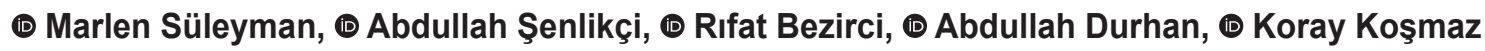 \\ Ankara Training and Research Hospital, Clinic of General Surgery, Ankara, Turkey
}

\section{HIIIIII| ABSTRACT}

Aim: Rectal foreign bodies are rare cases encountered in the emergency department. Taking the correct history and applying the correct treatment algorithm is important in the management of these cases. The aim of this study was to evaluate the patients who presented at the emergency department (ED) with a rectal foreign body.

Method: The study included patients who were evaluated by the general surgery department for rectal foreign body in the ED of Ankara Training and Research Hospital between January 2016 and December 2020. The patients were evaluated in terms of age, gender, foreign body type, clinical findings, imaging method, whether the surgery was performed, how the foreign body was removed, perforation, and anesthesia method.

Results: Out of 12 cases, the foreign bodies removed from each of the cases were a shampoo bottle, a bottle of black seed, a plastic bowling pin, an enema cover, a roll-on deodorant bottle, a spray deodorant bottle, a plastic toy ball, a lubricant gel bottle, a face toner bottle, a piece of wood, an effervescent tablets tube, and a tea cup, all of which having (8.3\%) each. The foreign body was used for sexual stimulation in 11 cases. Two of the cases had anorectal pain and two had abdominal pain. In six cases (50\%), the foreign body was removed rectally with spinal anesthesia. Two patients underwent laparotomy under general anesthesia, and in one (8.3\%) of these cases, colon perforation was determined, so Hartman colostomy was performed.

Conclusion: Patients presenting with rectal foreign bodies should be evaluated carefully, and acute abdominal perforation should be ruled out. Bodies causing distal lesions should be removed transanally with sedation or locoregional anesthesia. In cases with perforation, primary repair, segmental resection, or Hartman or loop colostomy should be performed according to the contamination status and perforation width.

Keywords: Rectal foreign body, management, anorectal trauma

\section{|IIIIIIII| ÖZ}

Amaç: Rektal yabancı cisimler acil serviste nadir görülen bir durumlardır. Bu olguların yönetiminde doğru öykünün alınması ve doğru tedavi algoritmasının uygulanması önemlidir. Bu çalışmanın amacı rektal yabancı cisim ile acil servise (AS) başvuran hastaları değerlendirmektir.

Yöntem: Çalışmaya Ankara Eğitim ve Araştırma Hastanesi AS’sinde Ocak 2016-Aralık 2020 tarihleri arasında rektumda yabancı cisim nedeniyle genel cerrahi bölümü tarafından değerlendirilen hastalar dahil edildi. Hastalar yaş, cinsiyet, yabancı cisim tipi, klinik bulgular, görüntüleme yöntemi, ameliyatın yapılıp yapılmadığı, yabancı cismin nasıl çıkarıldı̆̆ı, perforasyon ve anestezi yöntemi açısından değerlendirildi.

Bulgular: On iki olgudan her birinden $(\% 8,3)$ bir şampuan şişesi, bir çörekotu yağı şişesi, plastik bowling labutu, lavman kapağı, roll-on deodorant şişesi, sprey deodorant şişesi, plastik oyuncak top, bir kayganlaştırıcı jel şişesi, bir yüz toner şişesi, bir tahta parçası, bir efervesan tablet tüpü, bir çay bardağı gibi yabancı cisimler çıkarıldı. Yabancı cisim 11 olguda cinsel uyarı amacıyla kullanıldı. Olguların ikisinde anorektal ağrı, ikisinde karın ağrısı vardı. Altı olguda (\%50) yabancı cisim spinal anestezi ile rektal yolla çıarıldı. İki hastaya genel anestezi altında laparotomi yapıldı ve bu olguların birinde $(\% 8,3)$ kolon perforasyonu saptanarak Hartman tipi kolostomi yapıld.

Sonuç: Rektal yabancı cisim ile başvuran hastalar dikkatle değerlendirilmeli ve akut karın perforasyonu ekarte edilmelidir. Distal lezyonlara neden olan cisimler sedasyon veya lokal anestezi ile transanal olarak çıkarılmalıdır. Perforasyonlu olgularda kontaminasyon durumuna ve perforasyon genişliğine göre primer onarım, segmental rezeksiyon veya Hartman veya loop kolostomi yapılmalıdır.

Anahtar Kelimeler: Rektal yabancı cisim, yönetim, anorektal travma

Address for Correspondence/Yazışma Adresi: Abdullah Şenlikçi, MD,

Ankara Training and Research Hospital, Clinic of General Surgery, Ankara, Turkey

E-mail: asenlikci94@hotmail.com ORCID ID: orcid.org/0000-0002-4321-4004

Received/Geliş Tarihi: 23.12.2020 Accepted/Kabul Tarihi: 28.01.2021

${ }^{\circ}$ Copyright 2021 by Turkish Society of Colon and Rectal Surgery

Turkish Journal of Colorectal Disease published by Galenos Publishing House. 


\section{Introduction}

Rectal foreign bodies are difficult to diagnose and manage during the initial evaluation in the emergency department (ED) and continues after the removal too. ${ }^{1}$ These cases, which were very rare in the past, have increased in number in recent years. The annual incidence was reported as 0.15 per 1,00,000 people. ${ }^{2}$ However, the actual incidence of selfinserted rectal foreign bodies is unknown because patients only present at the ED if they cannot remove the foreign body or if acute abdominal pain develops. ${ }^{3}$ In addition, patients may be reluctant to tell the truth about the emergency admission, which may lead to a delay in detailed comprehensive assessment and diagnosis. ${ }^{4}$

The aim of this study was to retrospectively evaluate the patients who were admitted to the ED with a rectal foreign body and discuss the findings according to the relevant literature.

\section{Materials and Methods}

The study included patients who presented with a foreign body in the rectum between January 2016 and December 2020 at the ED of Ankara Training and Research Hospital. Patient information was obtained retrospectively from computer records and patient files. Cases with incomplete data were excluded from the study. The patients were evaluated in terms of age, gender, foreign body type, clinical findings, imaging method, whether the surgery was performed, how the foreign body was removed, perforation, and anesthesia method. All cases were evaluated in terms of acute abdomen first in the ED. Subsequently, the cases were evaluated in terms of whether the foreign body could be removed in the ED. In cases where the foreign body could be reached by rectal touch but could not be removed in the ED, it was removed in the operating room under spinal anesthesia. Once patients were observed to have normal abdominal examination and laboratory findings, they were discharged.

\section{Results}

A total of 12 patients were evaluated, comprising 10 (83.3\%) males and $2(16.7 \%)$ females with a median age of 34 years (range, 21-70 years). Removed foreign bodies are shown in Table 1 (Figure 1, 2).

The foreign body was found to be used for sexual stimulation in $11(91.6 \%)$ cases. In one case, the enema valve remained in the rectum after the enema application. Eight (66.6\%) of the cases were asymptomatic, two (16.6\%) had anorectal pain, and two (16.6\%) had abdominal pain. Rectal examination revealed lacerations in the anal mucosa in four patients. For the diagnosis, direct radiography was used in seven (58.3\%) cases, and computed tomography (CT) in four (33.3\%).

Table 1. Demographic and clinical characteristics of the cases

\begin{tabular}{|c|c|c|c|c|c|c|}
\hline Patient & Age & Gender & Foreign body & $\begin{array}{l}\text { Circumstances of } \\
\text { insertion }\end{array}$ & Clinical finding & Imaging method \\
\hline 1 & 25 & Male & Shampoo bottle & Sexual stimulation & Asymptomatic & Abdominal radiography \\
\hline 2 & 44 & Female & Bottle of black seed oil & Sexual stimulation & Abdominal pain & Abdominal radiography \\
\hline 3 & 40 & Male & Plastic bowling pin & Sexual stimulation & Asymptomatic & Abdominal tomography \\
\hline 4 & 31 & Female & Enema cover & Enema for constipation & Asymptomatic & - \\
\hline 5 & 21 & Male & Roll-on deodorant bottle & Sexual stimulation & Asymptomatic & Abdominal radiography \\
\hline 6 & 31 & Male & Spray deodorant bottle & Sexual stimulation & Asymptomatic & Abdominal radiography \\
\hline 7 & 24 & Male & Plastic toy ball & Sexual stimulation & Asymptomatic & Abdominal radiography \\
\hline 8 & 36 & Male & Lubricant gel bottle & Sexual stimulation & Abdominal pain & $\begin{array}{l}\text { Abdominal tomography } \\
+ \text { colonoscopy }\end{array}$ \\
\hline 9 & 27 & Male & Face toner bottle & Sexual stimulation & Anorectal pain & Abdominal tomography \\
\hline 10 & 70 & Male & Wood piece & Sexual stimulation & Anorectal pain & Abdominal tomography \\
\hline 11 & 63 & Male & Effervescent tablets tube & Sexual stimulation & Asymptomatic & Abdominal radiography \\
\hline 12 & 61 & Male & Tea cup & Sexual stimulation & Asymptomatic & Abdominal radiography \\
\hline
\end{tabular}



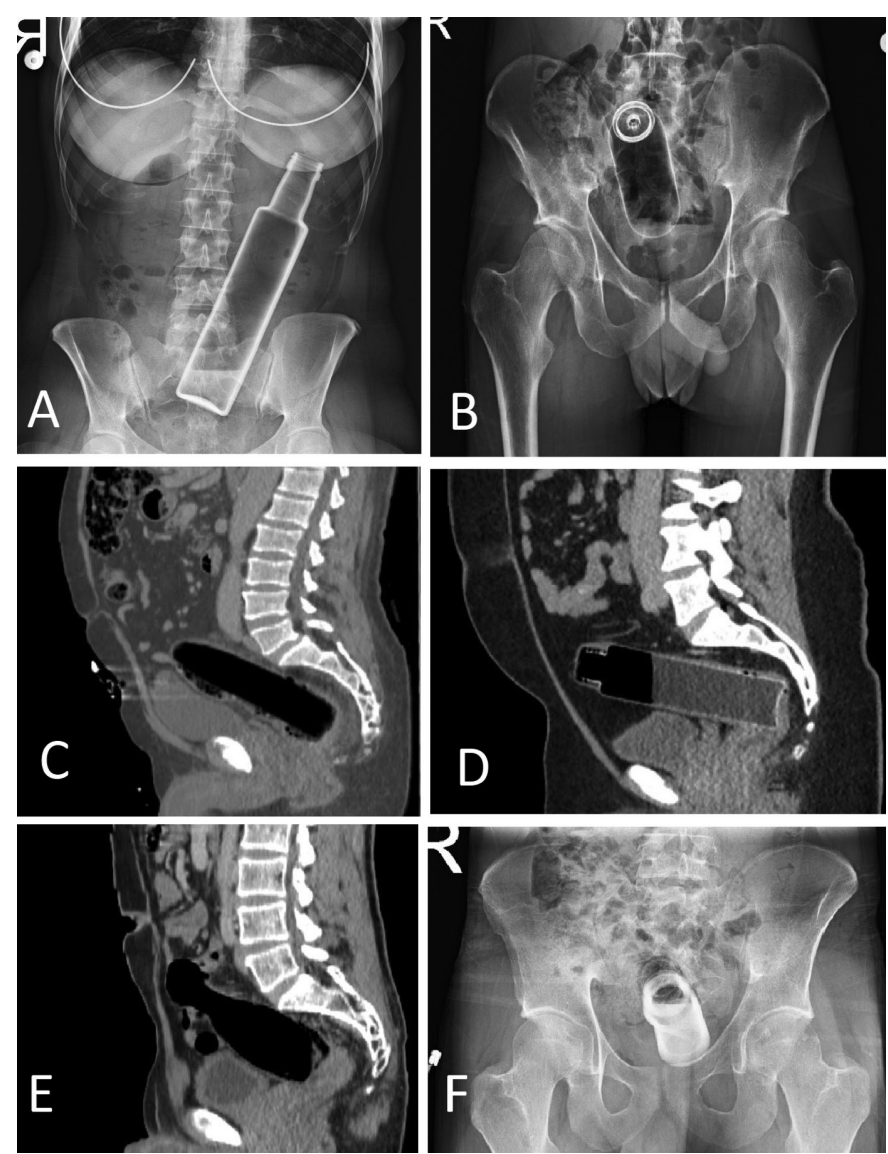

Figure 1. a) Bottle of black seed oil, b) Perfume bottle, c) Piece of wood, d) Shampoo bottle, e) Plastic bowling pin, and f) Roll-on deodorant bottle

In two cases, the foreign body was beyond the rectal touch distance. No test was performed for diagnosis in one (8.3\%) case (enema cover). In four (33.3\%) cases, the rectal foreign body was removed in the ED without anesthesia, and in six cases $(50 \%)$, it was removed rectally by administering spinal anesthesia. Two patients underwent laparotomy under general anesthesia. Colon perforation was present in one (8.3\%) of these cases; hence, Hartmann colostomy was performed. In the other case who underwent laparotomy, an attempt to remove the foreign body by colonoscopy after the CT evaluation was made. When it could not be removed by colonoscopy, laparotomy was performed, and the rectal foreign body was removed by milking the object transanally (Table 2). All the patients were discharged after clinical improvement was observed. No morbidity or mortality was observed in any of the patients.

\section{Discussion}

Surgeons and emergency physicians frequently encounter foreign bodies in the rectum. These objects vary widely, but the vast majority are sex toys, bottles, vegetables and

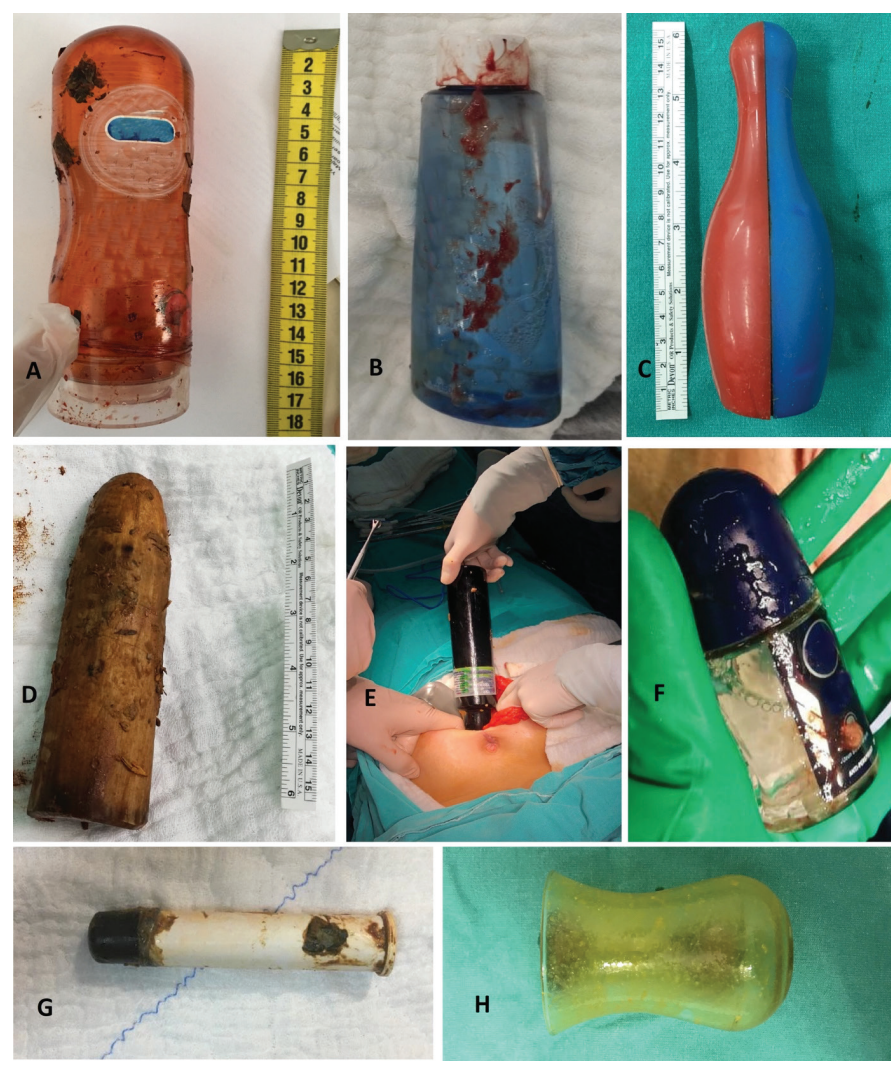

Figure 2. a) Lubricant gel bottle, b) Perfume bottle, c) Plastic bowling pin, d) Piece of wood, e) Bottle of black seed oil, and f) Roll-on deodorant bottle

fruits, and similar household items. ${ }^{1}$ In studies from other countries, rectal foreign bodies that were removed were predominantly sex toys. ${ }^{3,5,6}$ In the current series and in other series originating in Turkey ${ }^{4,7,8}$, the objects were of an ordinary domestic nature rather than sex toys. The reason for this may be the reluctance to shop in sex shops due to the social structure in Turkey. The rectal foreign bodies observed in the current study were a shampoo bottle, a bottle of black seed oil, a plastic bowling, an enema cover, a roll-on deodorant bottle, a spray deodorant bottle, a plastic toy ball, a lubricant gel bottle, a face toner bottle, a piece of wood (chipped shovel handle), an effervescent tablets tube, and a tea cup.

The most common reason for foreign body insertion is sexual stimulation. ${ }^{3,9}$ Other reasons are sexual assault, drug trafficking, amateur self-medical treatment, and objects used for constipation treatment. ${ }^{3}$ The most common cause of rectal foreign body in this series was autoeroticism and in one case, the reason was the enema valve remaining in the rectum after enema application.

In the literature, as in the current cases, the patients are mostly males between the ages of 11 and 80 years with a ratio of 6:1-37:1, and most commonly between the ages of 30 and 40 years. ${ }^{1,3,10,11}$ Patients usually wait for a while 
Table 2. Management of cases and complications

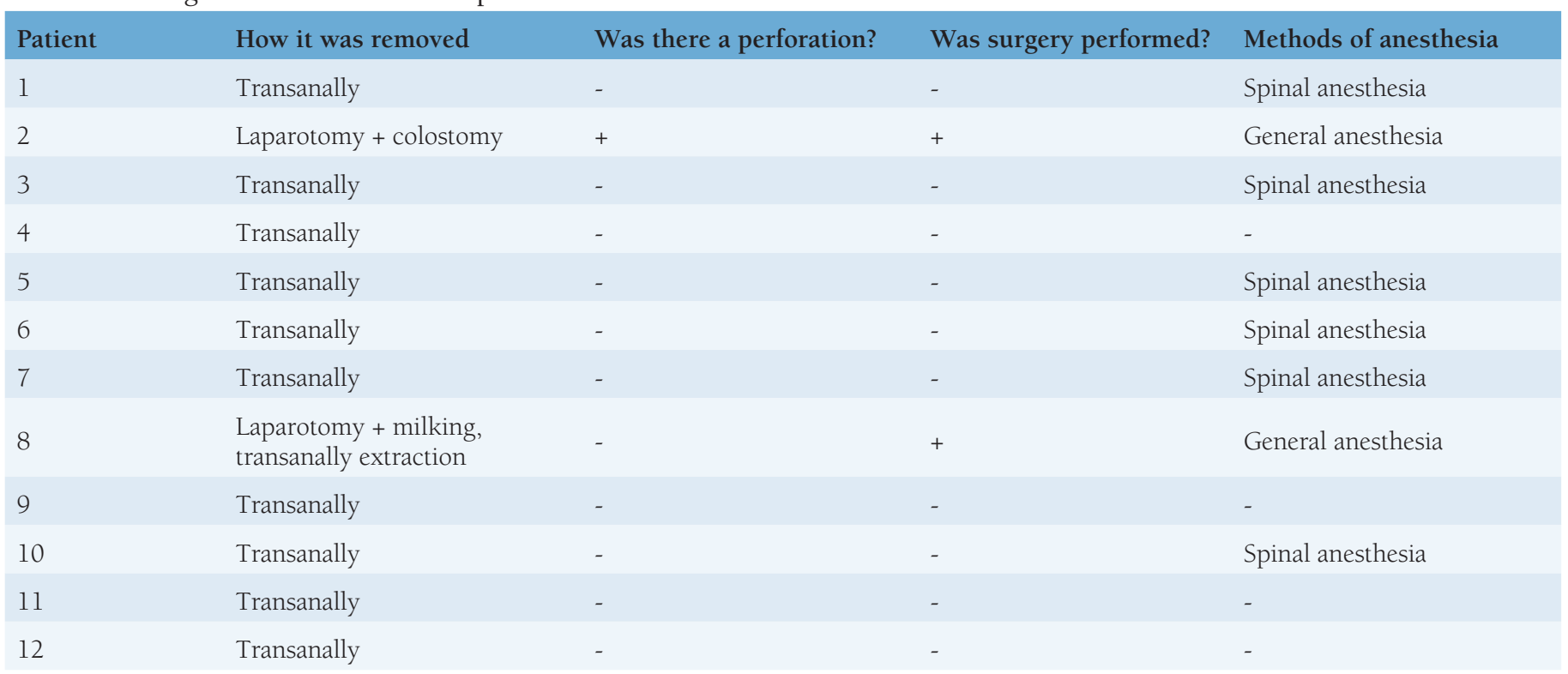

before coming to the hospital and try to remove it by themselves. ${ }^{12}$ A five-year pending case has been reported in the literature. ${ }^{13}$ Cases come to the ED only if self-removal fails or if abdominal pain develops. Therefore, the true incidence is unknown. ${ }^{3}$

Clinicians must be friendly and respectful to ensure reliable communication with patients presenting with a rectal foreign body. A respectful and professional approach, without judgment, enables the anamnesis to be taken more accurately and to be managed more quickly by diagnosis. ${ }^{2}$ The approach to rectal foreign bodies has been given in many articles. In these algorithms, the authors recommend starting with a detailed anamnesis from the patient before determining the treatment method. ${ }^{14,15}$ The type and volume of the object, and the time elapsed from the event to inspection should be asked. Another issue that should be considered is that patients are evaluated in terms of colon perforation. ${ }^{1,4}$ Detailed abdominal and rectal examinations should be performed in terms of the acute abdominal findings. Foreign bodies may be distinguished by digital rectal examination, which should be performed after abdominal radiography to avoid injury to the doctor with a sharp object. In addition, anal sphincters should be carefully evaluated for injury. ${ }^{4}$ Although sphincter damage was not observed in the current cases, anal mucosal damage was observed in four cases. Radiologically, direct abdominal radiographs are sufficient in most cases, and abdominal tomography should be performed when perforation is suspected.

Various techniques have been described for rectal foreign body extraction. The extraction technique varies according to many factors, such as the type, size, location of the object, the time from the event to the examination, the patient's symptoms, and the surgeon's experience. ${ }^{11}$ Most authors emphasize that in patients without acute abdominal findings, the foreign body may be removed in the emergency room without a surgery. The success rate of this procedure varies between $63 \%-74 \% .{ }^{11,16}$ Although anesthesia is not required when removing small, distally-located objects, locoregional or general anesthesia is required for highly located objects. ${ }^{1,10,17}$ In four of the current cases, the rectal foreign body was removed in the emergency room without any anesthesia, but in six patients, it was removed in the operating room under spinal anesthesia, and in two patients, under general anesthesia. Perforation possibility and acute abdomen should be excluded in patients for whom transanal extraction is considered. The foreign body may be expected to emerge spontaneously by giving laxatives or an enema when the object is small without a perforation risk. However, it should be noted that there is a risk of impaction, hemorrhage, and perforation in the rectum when using this method. ${ }^{18}$ When the case series in the literature are examined, many techniques have been described for transanal extraction other than manual extraction. In a previous series, the rectal foreign body was removed transanally in 81.9\%-95.5\% of the cases. ${ }^{5,19}$ Surgical treatment performed by laparotomy has been reported at a rate of $8 \%-10 \% .{ }^{11,18}$ Transanally, the foreign body may be removed manually or by using forceps, a Kocher clamp, or similar surgical tools, ${ }^{5,20}$ In addition, polypectomy snares, an inflated Foley catheter, a vacuum extractor, and endoscopic dilatation balloons have been used for extraction. ${ }^{11,21,22,23}$ Apart from these methods, cases 
in which a rectal foreign body was removed by placing a single incision laparoscopic surgery port in the anal canal have been reported..$^{24,25}$ Colonoscopic extraction may also be performed in appropriate cases. ${ }^{26}$ In the current series, the rectal foreign body was removed manually in 4 cases, and in a total of 11 cases (91.6\%), extraction was made transanally, of which 7 cases required the use of surgical instruments. Many authors recommend performing a control rectosigmoidoscopy after transanal removal of the rectal foreign body to rule out bowel injury and confirm the presence of multiple foreign bodies. . $^{14,15,16}$

Some patients require laparotomy or laparoscopy for rectal foreign body extraction. In particular, the possibility of laparotomy is high in patients where the foreign body has advanced to the sigmoid colon and proximally. ${ }^{11}$ In addition, laparotomy is indicated in patients with perforation (free air on x-ray) and acute abdomen. In patients without signs of peritonitis, the foreign body is milked distally through laparotomy or the laparoscopic method and removed from the anal canal. ${ }^{27,28}$ In early cases with perforation, laparoscopic or open primary repair may be performed after foreign body extraction. ${ }^{29}$ A loop or Hartman colostomy should be performed in patients who develop signs of major intra-abdominal contamination, peritonitis, or sepsis. ${ }^{17,30}$

\section{Conclusion}

Rectal foreign body is a rare condition. Before choosing the extraction method, patients should be evaluated carefully. In cases without acute abdomen, transanal extraction should be the first choice, preferably under sedation, and locoregional anesthesia should be used for rectal foreign bodies located in the distal rectum. Control abdominal radiographs, 24hour observation, and control with rectosigmoidoscopy are recommended in cases undergoing transanal extraction. It is essential to perform laparoscopy or laparotomy in cases where transanal extraction is unsuccessful or for highlocated foreign bodies. If there is no perforation, transanal removal should be attempted by pushing distally through milking. When this method fails, a colostomy should be performed. In cases with perforation, primary repair, resection of the damaged segment, and loop colostomy or Hartman colostomy are performed, depending on the general condition of the patient, the patient's comorbidities, time after perforation, intra-abdominal contamination, and peritonitis.

\section{Ethics}

Ethics Committee Approval: All procedures performed involving human participants were in accordance with the ethical standards of the institutional and/or national research committee and with the 1964 Helsinki Declaration and its later amendments or comparable ethical standards. Peer-review: Externally and internally peer reviewed.

\section{Authorship Contributions}

Surgical and Medical Practices: M.S., A.D., K.K., Concept: R.B., Design: A.D., K.K., Data Collection or Processing: R.B., Analysis or Interpretation: M.S., A.Ş., Literature Search: M.S., A.Ş., Writing: M.S., A.Ş.

Conflict of Interest: No conflict of interest was declared by the authors.

Financial Disclosure: The authors declared that this study received no financial support.

\section{References}

1. Goldberg JE, Steele SR. Rectal foreign bodies. Surg Clin North Am 2010;90:173-184, Table of Contents.

2. Cawich SO, Thomas DA, Mohammed F, Bobb NJ, Williams D, Naraynsingh $\mathrm{V}$. A management algorithm for retained rectal foreign bodies. Am J Mens Health 2017;11:684-692.

3. Ploner M, Gardetto A, Ploner F, Scharl M, Shoap S, Backer HC. Foreign rectal body - Systematic review and meta-analysis. Acta Gastroenterol Belg 2020;83:61-65.

4. Coskun A, Erkan N, Yakan S, Yildirim M, Cengiz F. Management of rectal foreign bodies. World J Emerg Surg 2013;8:11.

5. Kokemohr P, Haeder L, Fromling FJ, Landwehr P, Jahne J. Surgical management of rectal foreign bodies: a 10-year single-center experience. Innov Surg Sci 2017;2:89-95

6. Dahlberg M, Nordberg M, Pieniowski E, Bostrom L, Sandblom G, HallqvistEverhov A. Retained sex toys: an increasing and possibly preventable medical condition. Int J Colorectal Dis 2019;34:181-183.

7. Yildiz SY, Kendirci M, Akbulut S, Ciftci A, Turgut HT, Hengirmen S Colorectal emergencies associated with penetrating or retained foreign bodies. World J Emerg Surg 2013;8:25.

8. Cinar H, Berkesoglu M, Derebey M, Karadeniz E, Yildirim C, Karabulut K, Kesicioglu T, Erzurumlu K. Surgical management of anorectal foreign bodies. Niger J Clin Pract 2018;21:721-725.

9. Schellenberg M, Brown CVR, Trust MD, Sharpe JP, Musonza T, Holcomb J, Bui E, Bruns B, Hopper HA, Truitt MS, Burlew CC, Inaba K, Sava J, Vanhorn J, Eastridge B, Cross AM, Vasak R, Vercuysse G, Curtis EE, Haan J, Coimbra R, Bohan P, Gale S, Bendix PG; AAST Contemporary Management of Rectal Injuries Study Group. Rectal injury after foreign body insertion: secondary analysis from the AAST contemporary management of rectal Injuries Study Group. J Surg Res 2020;247:541-546.

10. Kurer MA, Davey C, Khan S, Chintapatla S. Colorectal foreign bodies: a systematic review. Colorectal Dis 2010;12:851-861

11. Lake JP, Essani R, Petrone P, Kaiser AM, Asensio J, Beart RW, Jr. Management of retained colorectal foreign bodies: predictors of operative intervention. Dis Colon Rectum 2004:47:1694-1698.

12. Couch CJ, Tan EG, Watt AG. Rectal foreign bodies. Med J Aust. $1986 ; 144: 512-5$.

13. Ozbilgin M, Arslan B, Yakut MC, Aksoy SO, Terzi MC. Five years with a rectal foreign body: a case report. Int J Surg Case Rep 2015;6C:210-213.

14. Ayantunde AA. Approach to the diagnosis and management of retained rectal foreign bodies: clinical update. Tech Coloproctol 2013;17:13-20.

15. Khubezov DA, Trushin SN, Puchkov KV, Puchkov DK, Ogorel'tsev AY. [Treatment of rectal foreign bodies]. Khirurgiia (Mosk). 2016:57-63. 
16. Cohen JS, Sackier JM. Management of colorectal foreign bodies. J R Coll Surg Edinb 1996;41:312-315.

17. Rodriguez-Hermosa JI, Codina-Cazador A, Ruiz B, Sirvent JM, Roig J, Farres R. Management of foreign bodies in the rectum. Colorectal Dis 2007;9:543-548.

18. Ooi BS, Ho YH, Eu KW, Nyam D, Leong A, Seow-Choen F. Management of anorectal foreign bodies: a cause of obscure anal pain. Aust N Z J Surg 1998;68:852-855.

19. Biriukov Iu V, Volkov OV, An VK, Borisov E, Dodina AN. [Treatment of patients with foreign bodies in rectum]. Khirurgiia (Mosk). 2000:41-43.

20. Yılmaz B, Ozmete S, Altınbas A, Aktaş B, Ekiz F. Successful removal of an unusual rectal foreign body with a Kocher clamp. Endoscopy 2014;46(Suppl 1) UCTN:E549. doi: 10.1055/s-0034-1377768.

21. Sayllır A, Düzgün IN, Güvendi B. Treatment of unusual rectal foreign body using a Foley catheter. Endoscopy. 2014;46(Suppl 1) UCTN:E182-E183. doi: 10.1055/s-0034-1365109.

22. Sei H, Tomita T, Nakai K, Nakamura K, Tamura A, Ohda Y, Oshima T, Fukui H, Watari J, Miwa H. Rectal foreign body of eggplant treated successfully by endoscopic transanal removal. Case Rep Gastroenterol 2018;12:189-193.
23. Feigelson S, Maun D, Silverberg D, Menes T. Removal of a large spherical foreign object from the rectum using an obstetric vacuum device: a case report. Am Surg 2007;73:304-306.

24. Elias B, Debs T, Hage S, Bassile B, Hanna P, Saint Eve P. Single incision laparoscopic surgery technique for transanal removal of rectal foreign body. J Surg Case Rep 2014;2014:rju022.

25. Han HJ, Joung SY, Park SH, Min BW, Um JW. Transanal rectal foreign body removal using a SILS port. Surg Laparosc Endosc Percutan Tech 2012;22:e157-e158.

26. Rocklin MS, Apelgren KN. Colonoscopic extraction of foreign bodies from above the rectum. Am Surg 1989;55:119-123.

27. Berghoff KR, Franklin ME, Jr. Laparoscopic-assisted rectal foreign body removal: report of a case. Dis Colon Rectum 2005;48:1975-1977.

28. Rispoli G, Esposito C, Monachese TD, Armellino M. Removal of a foreign body from the distal colon using a combined laparoscopic and endoanal approach: report of a case. Dis Colon Rectum 2000;43:1632-1634.

29. Najah H, Pocard M. Laparoscopic repair of rectal foreign body perforation without protective colostomy (with video). J Visc Surg 2015;152:69-70.

30. Arora S, Ashrafian H, Smock ED, Ng P. Total laparoscopic repair of sigmoid foreign body perforation. J Laparoendosc Adv Surg Tech A 2009;19:401403 